\title{
30 éve a szakértésben - az igazságügyi szakértői tevékenység múltja és jelene a Nemzetbiztonsági Szakszolgálat Szakértői Intézetben
}

Thirty Years of Expertise - The Past and Present of the Forensic Expert Activities in the Institute of Expert Services of the Special Service for National Security

A Nemzetbiztonsági Szakszolgálat Szakértői Intézete olyan intézmény, amelynek szakértői tevékenysége kiterjed mind a müveleti szakos (titkos információgyüjtéssel összefüggő), mind a nyílt szakos ügyekre (hatósági, szakhatósági és igazságügyi szakértés), így mondhatjuk, hogy a szakértöi intézetek körében privilegizált helyzetben van. Jelen tanulmány célja az intézetben folyó igazságügyi szakértői tevékenység gyakorlatának bemutatása, különös figyelmet szentelve az elmúlt 30 év kiemelt jelentőségü büncselekményeinek feltárásában nyújtott szakértelmünknek.

Kulcsszavak: Szakértői Intézet, igazságügyi szakértés, okmányszakértés, írásszakértés, nyelvész szakértés, vegyész szakértés, hangtechnikai szakértés, fotó és videotechnikai szakértés, informatikai szakértés

The Institute for Expert Services of the Special Service for National Security is an institute the expert activities of which cover both the operational cases (concerning secret intelligence gathering) and the judicial cases (performing regulatory, authoritative and forensic expertise). Therefore we can claim that our institute is in a privileged position. The purpose of the present study is to give an overview of the forensic expert activities carried out by the Institute for Expert Services, paying special attention to our expertise regarding the exploration of priority crimes in the past thirty years.

Keywords: Institute for Expert Services, forensic expert activity, document-, handwriting-, and linguistic expert, analysis of explosives, photo-video expert, speech and audio analysis expert, IT expert 


\section{Bevezetés}

A Magyar Köztársaság Országgyúlése 1990-ben megalkotta az 1990. évi X. törvényt, amely az újonnan létrehozott nemzetbiztonsági szolgálatokat és a rendőrséget is felhatalmazta különleges titkosszolgálati eszközök és módszerek alkalmazására. Még ugyanezen évben a kormány elfogadta a 26/1990. (II. 14.) MT rendeletet a nemzetbiztonsági feladatok ellátásának átmeneti szabályozásáról, amellyel két polgári és két katonai nemzetbiztonsági szolgálat - Információs Hivatal, Nemzetbiztonsági Hivatal, Katonai Felderítő Hivatal és Katonai Biztonsági Hivatal - kezdte meg működését 1990. március 1-jével. Az 1990. évi - úgynevezett átmeneti - törvényt követően az Országgyúlés 1995 decemberében megalkotta a nemzetbiztonsági szolgálatokról szóló 1995. évi CXXV. törvényt (Nbtv.). Az Nbtv. a Nemzetbiztonsági Szolgálatot (NBSZ) - a Nemzetbiztonsági Hivatalról leválasztva - mint ötödik nemzetbiztonsági szolgálatot az ország egész területére kiterjedő illetékességgel rendelkező szolgáltató szervként határozza meg. Az NBSZ a törvényben rögzített feladatok ellátásával, a nyílt és titkos információgyújtés eszközeivel és módszereivel elősegíti Magyarország nemzetbiztonsági, bűnüldözési és bünfelderítési érdekeinek érvényesítését. Helyét, szerepét és feladatait tekintve speciális helyzetű a többi szolgálathoz képest, ugyanis nem végez önállóan bűnüldözési feladatokat, kizárólag az erre jogosult szervezetek megrendelése alapján nyújt szolgáltatásokat.

A Nemzetbiztonsági Szakszolgálat Szakértői Intézetének feladatkörét a már említett Nbtv. és egyéb jogszabályok részletezik, konkretizálják - például a szakterületek ágazati követelményeiért felelős szervek kijelöléséről, valamint a meghatározott szakkérdésekben kizárólagosan eljáró és egyes szakterületeken szakvéleményt adó szervekről szóló 282/2007. (X. 26.) Korm. rendelet -, amely feladatok az alábbiak:

- okmányvédelemmel kapcsolatos hatósági, szakhatósági feladatkörben végzett szakértői tevékenység végzése az Nbtv. 8. § (1) bekezdés d) pontja, a biztonsági okmányok védelmének rendjéröl szóló 86/1996. (VI. 14.) Korm. rendelet és az általános közigazgatási rendtartásról szóló 2016. évi CL. törvény alapján;

- múveleti célú szakértői támogatás nyújtása az Nbtv. 8. § (1) bekezdés e) pontja alapján a titkosszolgálatoknak és a titkosszolgálati eszközök alkalmazására jogszabály alapján feljogosított nyomozati szerveknek;

- igazságügyi szakértői tevékenység ellátása az Nbtv. 8. § (1) bekezdés e pontja és az igazságügyi szakértőkről szóló 2016. évi XXIX. törvény (Sztv.) alapján a bűnüldöző szervek, bíróságok, ügyészségek megrendelésére országos hatáskörrel.

Lévén a Szakértői Intézet egy polgári nemzetbiztonsági szolgálat szervezeti egysége, fő tevékenységi körünk értelemszerűen nemzetbiztonsági érdekek mentén szerveződik. Az előzetes szakértői vélemény, amely a müveleti munkát hivatott támogatni, bíróság előtti felhasználásra nem alkalmas. Előzetes szakértői véleményt a nemzetbiztonsági szolgálatok és a különleges eszközök alkalmazására jogszabály alapján feljogosított 
nyomozati szervek kérhetnek, ${ }^{2}$ hiszen ezekben a szakértő a titkos információgyűjtés alkalmával felmerült szakkérdésekre adott válaszával nagymértékben befolyásolja, alakítja a műveleti munka irányát, ezzel segítve a bűnüldöző szervek munkáját és a búncselekmény feltárását. Az intézet emellett nyílt szakban is készít szakértői véleményeket - törvény szabta hatósági, szakhatósági véleményezés, valamint büntetőeljárásokban igazságügyi szakértés -, vagyis speciális szakértői kapacitással rendelkezik, szakértőinek tudása sokirányú szakmai bázison alapszik, és ez adja azt a szakértelmet, szaktudást, amely alapján a Nemzetbiztonsági Szakszolgálat az igazságügyi szakértői feladatok ellátására is kirendelhető, hogy: „[A] hatóság kirendelése vagy megbízás alapján, a tudomány és a múszaki fejlődés eredményeinek felhasználásával készített szakvéleménnyel, a függetlenség és pártatlanság követelményének megtartásával döntse el a szakkérdést, és segítse a tényállás megállapítását."3

A Szakértői Intézet elmúlt 30 évben végzett szakértői tevékenységének bemutatásához nélkülözhetetlen valamiféle szegmentálás, amelyre reflektálva felfüzhetők azok a tényezők, amelyek az anyaszervezet, az intézet, a szakértés és azon belül az igazságügyi szakértői tevékenység kialakulásához, változásához, fejlődéséhez vezettek. Adná magát, hogy a 30 éves időszakot három 10 éves ciklusra osszuk fel, azonban az idő múlása mellett több minden idézte elő a szervezeti innovációt: elsősorban magyarországi jogi, társadalmi, gazdasági, logisztikai, technikai stb. változások, illetve a nemzetközi trendekhez való alkalmazkodás is. Releváns történés például az elmúlt 30 évben a NATO- (1999) és EU- (2004) csatlakozásunk, a köztársasági államforma megteremtése, a búnüldöző szervek struktúrájának átalakítása; feladatspecifikus munkafolyamatok létrejöttéhez vezettek a nemzetbiztonsági és rendvédelmi megrendelő szervek részéről megfogalmazott igények (amelyek a bünözői magatartásokra reagáltak), a jogszabályi felhatalmazás és nem utolsósorban a technikai fejlődés is.

\section{0-1995: a jogi keretek kialakulása}

1989-től kezdődően a Szakértői Intézetben folyó munkát érezhetően befolyásolta a politikai és gazdasági környezet változása, a szervezeti strukturális átalakítás és az ezzel járó jelentős munkaerő-átcsoportosítás. Bizonyos feladatok megszúntek, újabbak, eddig ismeretlen igények jelentkeztek, az intézetnek pedig alkalmazkodnia kellett a megváltozott körülményekhez. 1989-ben, a rendszerváltás évében a Nemzetbiztonsági Szakszolgálat Szakértői Intézet jogelődje, a Nemzetbiztonsági Hivatal Szakszolgálati és Technikai Igazgatóságának T-2. Osztálya látta el a szakértői feladatokat. A szakterületek létrehozása azonban már 1970-es évek elején (1972-ben) megkezdődött, ekkor jött létre ugyanis a BM Okmányszakértői Iroda, így a már korábban is végzett okmányvédelemmel, okmányfejlesztéssel összefüggő feladatokhoz okmányszakértői képesség is társult. A mai napig igen szoros a szakmai együttmúködés az intézetben az okmányvédelemmel és -fejlesztéssel foglalkozó szakemberek és az okmányszakértők

Az Nbtv. alapján a három „klasszikus” nemzetbiztonsági szolgálat mellett (Információs Hivatal, Alkotmányvédelmi Hivatal, Katonai Nemzetbiztonsági Szolgálat) a megrendelők rendvédelmi/bűnüldöző szervek (rendőrség, ügyészség, Nemzeti Védelmi Szolgálat, Terrorelhárítási Központ, Nemzeti Adó- és Vámhivatal). Sztv. 3. § (1) bekezdés. 
között, ugyanis a két terület erőteljesen hat egymásra: az okmányszakértői tevékenység során megszerzett tapasztalatok megmutatják, hogy melyek a hamisítók által leginkább támadott részei egy okmánynak, és ezen tudás, információ birtokában tervezhetőbbé válik az okmányvédelem. ${ }^{4}$

Közvetlenül a rendszerváltást követő években a Nemzetbiztonsági Szakszolgálat jogelődjénél a rendőri szervek megrendeléseinek aránya mindössze 5\% volt; ez az arány szakértői szinten hozzávetőlegesen 40\%, azonban már a kilecvenes évek elején folyamatosan emelkedett a rendvédelmi szervek kirendeléseinek száma (kezdetben 70\% körüli volt, majd a 2000-es évekre elérte a 90\%-ot is). Ahogy a társadalmi berendezkedésünk, úgy a szervezetünk is egyre nyitottabbá vált: egyértelmű volt, hogy az intézetben felhalmozódott értékes szakértői tudást meg kell osztani a nyomozó hatóságokkal is, hogy azok ne csak a nemzetbiztonsági szolgálatok érdekeit szolgálják.

1990-ben a Szakértői Intézet jogelődjénél összesen négy szakértői terület múködött. Egy átszervezést követően az okmányszakértőkkel összevonták az írás- és nyelvész szakértőket, így jött létre az Okmány- és Írásszakértői Iroda tulajdonképpen három szakterülettel.

Az okmányszakértői vizsgálatok annak megállapítására irányulnak, hogy az okmány vagy irat:

- alapanyagait, előállításmódját, védelmi megoldásait tekintve eredeti-e;

- egyes elemei eredetiek-e;

- kitöltését és hitelesítő megoldásait tekintve hitelesnek tekinthető-e;

- történt-e benne bármilyen illetéktelen beavatkozás, utólagos változtatás, azaz a vizsgálati tárgy tartalmilag hamisított-e;

- amennyiben történt változtatás, azt milyen módszerekkel és milyen eszközök alkalmazásával hajtották végre;

- részben vagy egészben hamisítvány-e;

- és ha igen, milyen módon és milyen eszközökkel történt az előállítása.

Az írásszakértői vizsgálatok tárgya bármilyen kézzel írott szöveg vagy aláírás, a szakértők pedig a következő kérdések esetén rendelhetők ki:

- a kérdéses kézzel írott szöveget vagy aláírást a megküldött írásminták alapján ki készíthette;

- több kézírás ugyanattól a személytől származik-e;

- azonos nevet tartalmazó aláírások egy személytől származnak-e;

- az iraton lévő kézírást vagy aláírást, annak egyes részeit megváltoztatták-e;

- az írógéppel készített szöveget milyen típusú írógéppel állították elő, meghatározott írógépen írták-e, illetve különböző gépelt szövegeket ugyanazon az írógépen írtak-e.

A nyelvész szakértői vizsgálat tárgya elsősorban zsaroló, fenyegető, zaklató, becsületsértő, rágalmazó ügyekben keletkezett írásmú, amely bármilyen kivitelezési eljárással 
készülhetett (kézírás, számítógép, betűragasztás stb.). A nyelvész szakértő az alábbi kérdésekre adott válaszával segítette a kirendelő szerveket:

- a kérdéses írásmü fogalmazója-szerzője milyen nemü, életkorú, iskolázottságú, anyanyelvű, nyelvjárási területről származó stb. személy (csoportbehatárolás/ fogalmazóprofil-alkotás);

- több kérdéses írásmú esetében a fogalmazó-szerző azonos-e (azonosítás);

- a kérdéses írásmű(vek)et a gyanúsított személytől származó összehasonlító szövegminták alapján a gyanúsított írta-e (szerzőazonosítás);

- az inkriminátum torzított-e; az inkriminátum fogalmazója és kivitelezője ugyanaz a személy-e (diktálás, másolás).

Ezek a feladatok 1990-től kezdve adottak, ami azt jelzi, hogy klasszikus kriminalisztikai szakterületekről van szó; ami változott, az a törvényi determináció (az okmányszakértői vizsgálatok tárgyait a korábban már említett 86/1996. (VI. 14.) Korm. rendeletben felsorolt okmányok, iratok adják) és a technikai fejlődés „számlájára írható” (például a nyelvészeti vizsgálatok tárgya napjainkban az internetes szöveg).

A kilencvenes évek eleje az útkeresésről szólt, és az ezzel járó változások, változtatások leginkább az Okmány- és Írásszakértői Iroda mellett működő negyedik szakterületet, a vegyészetet érintette. Az időszakra jellemző vegyész szakértői vizsgálódások fő irányvonala a kábítószer-analitika volt (vö. a designerdrogok és a marihuána térhódítása), ugyanakkor a kilencvenes évek közepén uralkodó közéleti és társadalmi események (tudniillik robbantásos büncselekmények) miatt a robbanószer-analitika terület kiépítésének lehetősége is felmerült. Ebben az időszakban a Bünügyi Szakértői és Kutatóintézet (BSZKI) - a Nemzeti Szakértői és Kutató Központ (NSZKK) elődje - már végzett kábítószer-vizsgálatot, de robbanóanyag-analízist nem, vagyis Magyarországon nem volt szakértői intézményi keretek között múködő robbanóanyag-vizsgálat. A labor kiépítéséhez felvettük a kapcsolatot az Építéstudományi Egyesület Robbantástechnikai Szakosztályának vezetőjével, és az általa nyújtott szakmai segítséggel és a saját maga kialakította könyvtárban 5 gújitött szakirodalom felhasználásával, valamint a Mechanikai Múvektől kapott támogatással - amely intézet más egyebek mellett robbanóanyag kiszereléssel foglalkozott, és kutatásokat végzett a Haditechnikai Intézetnek - vegyész szakembereink kialakították a laboratóriumot. 1994-95-ben összesen hét robbantás (például Mátyás-templom, Práter és Paskál utcai autórobbantások, Parlament 19. kapuja) körülményeinek feltárásában segédkeztek vegyészeink, és ettől kezdve az intézet vegyész szakértői vizsgálatai a következőképpen alakultak:

- milyen fő komponensek, hatóanyagok mutathatók ki a kémiai elemzésre megküldött anyagokban, anyagmintákban;

- kimutatható-e robbanóanyag, illetve kábítószer, pszichotróp anyag, új pszichoaktív anyag (designerdrog) a mintában;

- milyen úton állíthatók elő a kémiai elemzések során azonosított fő komponensek, hatóanyagok, azok beszerezhetők-e kereskedelmi forgalomban, ha

A Robbantástechnikai gyűjtemény jelenleg a Nemzeti Közszolgálati Egyetem (NKE) Központi Könyvtárában van. www.mare.info.hu (A letöltés dátuma: 2019. 10. 17.) 
igen, milyen korlátozásokkal, továbbá alkalmasak-e kábítószer, robbanóanyag, illetve az emberre és környezetére veszélyes egyéb vegyi anyag előállítására.

Az Okmány- és Írásszakértői Iroda 1990 és 1995 között hozzávetőlegesen 4000 db szakértői véleményt készített. 1991-re az okmány-, írás- és nyelvész szakértői vélemények száma megnyolcszorozódott (!) és a rendőri kirendelések aránya emelkedett. A legnagyobb ügyszámot az okmányszakértés produkálta; az időszak legérdekesebb kirendelése három darab 1 milliárd forint összegű hamis bankgaranciát biztosító irat szakértése (az Országos Rendőr-főkapitányság), valamint fényképcserés személyigazolványok, illetve az ezekkel kiváltott, majd meghamisított Postabank Betétszámlakönyvek vizsgálata volt (Tiszaújvárosi Rendőrkapitányság). A kilencvenes évek elején a szeszesitalzárjegy nyomdatechnikai úton megvalósított, tömeges hamisításával összefüggő okmányszakértői vizsgálatokra volt még leginkább kereslet (több mint 14 ezer db hamis zárjegyről van szó).

1995-ben a Budapesti Rendőr-főkapitányság (BRFK) rendelte ki az írásszakértőket olyan ügyben, amikor nyilvános távbeszélő-készülékek feltörésével megszerzett érméket az elkövetők postán és bankfiókokban váltottak be, és a beváltáskor keletkezett több mint 850 db bizonylat és a hozzá tartozó összehasonlító írásminták komparatív vizsgálatát végezték el.

Megjelent a múveleti grafológia mint új szolgáltatás (a szövegek készítőjének személyiségjegyeire vonatkozó megállapítások), a nyelvész szakértésben pedig a terrorcselekménnyel fenyegető névtelen levelek fogalmazóinak felderítését célzó vizsgálatok jelentettek kihívást.

Fontos esemény 1995-ben az igazságügyi szakértői kamaráról szóló CXIV. törvény megszületése, amelynek kapcsán intézetünk a kezdetektől aktív szerepet vállalt a Magyar Igazságügyi Szakértői Kamara Kriminalisztikai tagozatának munkájában.

\section{6-2000: a 20. század vége}

1996-ban megváltozott a szervezeti struktúra, és létrejött a tulajdonképpen mai napig fennálló intézeti tagolódás: a Szakértői Intézet igazgatósággá nőtte ki magát, és két főosztállyal müködött tovább, amelyek már nevükben is tükrözték az általunk végzett tevékenységek megkülönböztetését: Szakértői Főosztály és Hatósági Főosztály.

A Szakértői Főosztály kirendelései 70-75\%-ban rendőri szervekhez köthetők, amely tendencia tartotta magát egészen az ezredfordulóig. 1995-ről 1996-ra, egyetlen év leforgása alatt az okmányszakértői kirendelések száma megduplázódott: főleg hazai gépjárművezetői engedélyek és forgalmi engedélyek, műszaki érvényesítő címkék vizsgálatait végeztük (az összes okmányszakértői kirendelés mintegy 80\%-át képezték ezek az okmányok, iratok). Amíg korábban a tartalmi hamisítás volt jellemző, addig a kilencvenes évek derekán a nyomdatechnikai úton előállított hamis okmányok szaporodtak el. Új tendencia a területen a hamis értékpapírok nyomdai úton való előállítása (a kárérték milliárdos nagyságrendű), valamint a hamis étkezési utalványok megjelenése. 
1996 és 2000 között az Analitikai Osztály tevékenysége robbanóanyagok, kábítószerek és okmányok különböző bünügyi szituációhoz kapcsolódó analitikai vizsgálataira terjedt ki leginkább: amfetaminszármazékok (Extasy, Speed, Love) azonosítását, valamint a repülőtéren a hatóságok által lefoglalt, Hollandiában vásárolt, eredeti csomagolású marihuánát, kannabiszmagot, gombaspórát tartalmazó minták vizsgálatát végeztük el. Változatlanul kiemelt jelentőségűek voltak a robbantásos ügyek, 1996 és 2000 között összesen 48 eseménnyel kapcsolatban kereste fel a nyomozóhatóság a vegyész szakértőinket. Az elkövetők ebben az időszakban a házilag könynyen előállítható anyagokat kedvelték (vö. Galaxy Night Club - fekete lőpor; Leroy étterem, Visegrádi utca - TNT kézigránát; Piliscsaba, távolsági busz - nitroglicerin stb.). 1996-ban a vegyészek és nyelvészek közös ügyön dolgoztak: vegyész szakértői vizsgálatok alapján az esztergomi Joker $A B C$ „ketchupos robbantó” néven elhíresült elkövetőről és a fent említett piliscsabai Volánbusz-járat robbantójáról megállapítást nyert, hogy azonos személy. A 17 éves középiskolás gyanúsított személytől vett szövegminta és a robbantásokkal kapcsolatban keletkezett névtelen zsaroló levelek összehasonlító vizsgálata alapján az elkövető személyt is beazonosították.

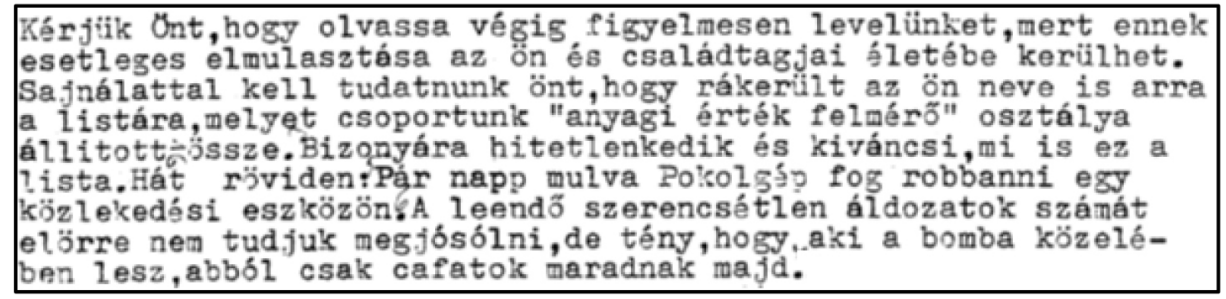

1. ábra

Részlet a fent emlitett ügyben keletkezett egyik névtelen fenyegető-zsaroló levélből

Forrás: Nemzetbiztonsági Szakszolgálat Szakértői Intézet (vizsgálati anyag)

A rendőri szervek részéről több esetben merült fel igény beszélőazonosításra, amely tevékenységet - jobb híján - a nyelvész szakértő végezte a hanganyag leiratán keresztül, feltárva és összehasonlítva a két (vagy több) beszélő nyelvhasználati sajátosságait. Ez a módszer hosszabb hanganyagok esetében jól múködött (lévén a hosszabb szövegekben jobban előtérbe kerülhetnek az egyedi stílussajátosságok), ugyanakkor az inkriminált hanganyagok hossza a legritkább esetben felelt meg az ilyen típusú összehasonlító vizsgálatnak (tudniillik nem jellemző, hogy valaki hosszan fenyegetne telefonon bombarobbantással). Ebben az időben együttműködési megállapodás született az MTA Nyelvtudományi Intézet Fonetikai Osztályával, és ezt a kifejezetten profiljukba vágó, beszédkutatással kapcsolatos feladatot ők végezték el számunkra, hiszen akkortájt már évek óta foglalkoztak akusztikai-fonetikai alapú beszélőazonosítással. 


\section{1-2010: szakterületi bővítések}

2000 után hirtelen ugrásszerüen megnőtt a rendőrségi kirendelések száma: az eddigi 70\% körüli arány 90-94\% között mozgott ebben a 10 éves intervallumban, ami mind a büntető-, mind a polgári peres eljárások keretében történő kirendelésszámokban jelentkezett. Nem arról van szó, hogy a múveleti szakos ügyeink száma csökkent volna, a főbb megrendelők ugyanúgy számítanak szakértelmünkre, mint korábban, ám az ügyszámemelkedés kifejezetten a nyílt szakos kirendeléseket érintette. Az okmányszakértői területen 2002-ben új elem a magyar személyigazolvány megtévesztésre kiválóan alkalmas teljes hamisítványainak felbukkanása, de tendenciajellegúvé kezd válni a gépjármúvezetői engedélyek hamisítására irányuló tevékenység is. Az új útlevelek fényképmanipuláció útján igen színvonalasan kivitelezett hamisításának gyakorisága csökkent: ennek oka, hogy a Budapesti Határőr Igazgatóság nagyszabású akcióban az év folyamán két hamisító múhelyt is felfedett, ezáltal a hamis okmányok utánpótlása megszűnőben volt. A Fővárosi és Megyei Bíróságokon, Cégbíróságokon benyújtott iratokon szereplő nagy tömegű hamis illetékbélyeg került hozzánk szakértői vizsgálatra (megközelítőleg 1 milliárd 300 millió Ft értékben). A hamisításokkal kapcsolatos szakértői tapasztalatainkat jeleztük a Pénzügyminisztérium felé, amelynek eredményeképpen az illeték lerovásának rendszerét módosították, és az illetékbélyegeket elóállító Pénzjegynyomda Rt. a bélyegek védelmi rendszerének áttervezését követően újabb, jobban védett bélyegváltozatokat bocsátott forgalomba.

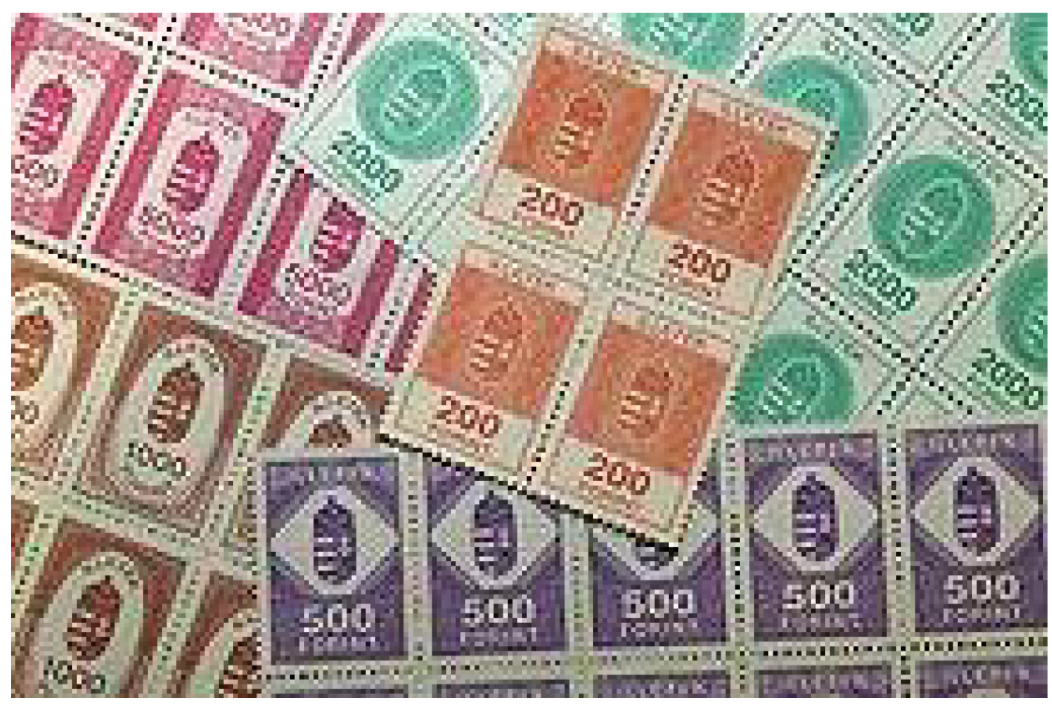

2. ábra

Illetékbélyeg-hamisitás

Forrás: https://origo.hu/gazdasag/20040218megszuntetnek.html (A letöltés dátuma: 2019. 10. 29.) 
Az Európai Unióhoz történt csatlakozásunk hatással volt néhány szakterület kirendeléseire: egyre nőtt a BM Bevándorlási és Állampolgársági Hivatal (BÁH) Menekültügyi Igazgatóság általi megkeresések száma, elsősorban iraki, afgán, kameruni, nigériai okmányok (leggyakrabban személyigazolványok, úti okmányok) vonatkozásában. 2008-tól megnövekedett azoknak az ügyeknek a száma, amelyekben román személyigazolványok (teljes hamisítványok), illetve bolgár személyigazolványok és vezetői engedélyek (arckép és adatcsere útján megvalósított hamisítás) képezték a vizsgálat tárgyát. A román és bolgár okmányok számszerű emelkedésének oka abban keresendő, hogy Románia és Bulgária is csatlakozott a Schengen-övezethez, és e két ország személyi okmányainak hamisításával próbáltak harmadik országok (leginkább Moldávia) polgárai bejutni az unió területére.

Az írásszakértői területen a gépjárművek adásvételi szerződéseinek vizsgálati gyakorisága pregnáns (az iratok népszerűségét jelzi, hogy az összes írásszakértői kirendelés 60\%-át teszik ki); a szerződések „eladó” rovatában lévő aláírások hamisításával a gépjármú átírási költségeit próbálták megspórolni. Az adásvételi szerződések mellett kiemelt jelentőségű volt a BRFK által folytatott nyomozás során vizsgált orvosi vény esete: a vényeket az elkövetők az orvosi bélyegzőlenyomatokkal ellátva lopták el, majd azokat a gyógyszerészek töltötték ki. A felírt gyógyszerek magas TB-támogatottságúak voltak, amellyel több mint 30 millió forintot igényeltek vissza a TB-től. Az időszakban 736 db választási ajánlószelvényt vizsgáltak meg az írásszakértők, illetve a Nógrád Megyei Rendőr-főkapitányság megbízásából egyedi azonosító jel meghamisításának bűntette miatt indult eljárásban 155 db különböző iraton (adásvételi szerződés, számla, meghatalmazás stb.) fellelhető kézírásokat és aláírásokat (kb. 600 db) vetették össze 53 személy írásmintájával.

A robbantásos események száma - szerencsére - lecsökkent (2001 és 2010 között 13 robbantásos esetben végeztünk robbanóanyag-vizsgálatot); a korszak releváns eseménye a törökbálinti Piro-Tech Kft. telephelyén bekövetkezett robbanás, valamint a Vám- és Pénzügyőrség Bűnügyi Igazgatóságának nagyszabású, egész országra kiterjedő alkoholhamisítási ügye volt 2006-ban: több száz minta (alkohol, szárazanyag, denaturáló szer) tartalmának meghatározása volt a vegyészek feladata. 2009-ben a Magyarok Nyilai szervezettel kapcsolatosan végzett nyomozás során bizonyítást nyert, hogy a megfigyelés alá volt személyek házilagos robbanóanyagok előállításával foglalkoztak, amelyeket saját készítésű szerkezetekben használtak robbanótöltet gyanánt.

Az egyre növekvő megrendelői igényeket kielégítendő a hangtechnikai szakértői terület megvalósítása nem várhatott tovább. Az MTA Nyelvtudományi Intézet Kempelen Farkas Beszédkutató Laboratóriuma továbbra is akusztikai szakértői vizsgálatokat végzett számunkra, és segítette az intézetünk eszközparkjának kiépítését, valamint nem utolsósorban képzéseket tartott leendő hangtechnikai szakértőinknek. ${ }^{6}$ 2003-ban megkezdődött a hangtechnikai szakértés, amelynek keretében a szakértők a következő feladatokat, vizsgálatokat végzik el: 
- beszélőazonosítás: beszéd alapján történő személyazonosítás általunk rögzített hangminta alapján, vagy ismeretlen személyazonosságú beszélók beszédének összevetése az azonosság megállapítása céljából;

- hangfelvételek zaj és torzítás csökkentése, tisztítása, a beszédérthetőség javítása;

- hangfelvételek eredetiségvizsgálata: manipulációs jegyek (vágási, szerkesztési, rögzítő eszköz ki- és bekapcsolási jelek) felfedésére irányuló vizsgálatok;

- egyéb, hangfelvételekkel kapcsolatos szakértői feladatok: beszélőprofil-készítés, konvertálás, szerkesztés, másolás, jegyzőkönyv készítése (leiratozás) stb.

A 2008-as évben kiemelt ügynek számított a Pest Megyei Rendőr-főkapitányság kirendelése közveszéllyel fenyegetés bűntette miatt (bombarobbantás, 107-es hívószám), valamint a Szécsényi Rendőrkapitányság készpénz-helyettesítő fizetési eszköz meghamisításának búntette miatt folytatott eljárása. Utóbbi ügyben az elkövető a CIB-bank ügyfélszolgálatát hívogatta különböző neveken bemutatkozva; a hangszakértők fonetikai alapú összehasonlító vizsgálattal megállapították, hogy a pszeudonim telefonáló minden esetben ugyanaz a személy volt.

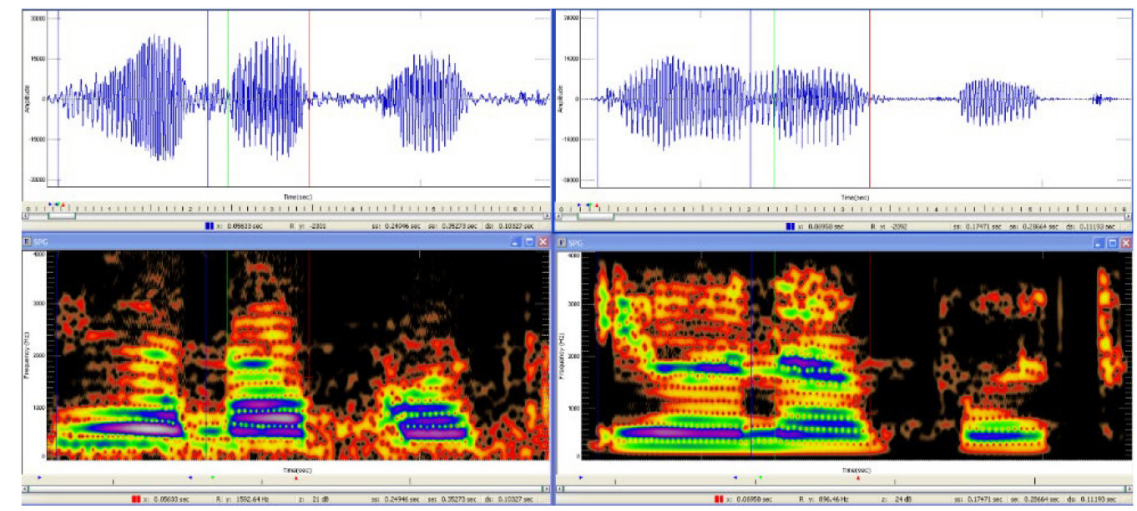

3. ábra

A „jó napot" hangsor: bal oldalon a kérdéses személy, jobb oldalon a gyanúsitott személy spektogramja

Forrás: Nemzetbiztonsági Szakszolgálat Szakértői Intézet (vizsgálati anyag)

A szakterületi fejlesztés és profiltisztítás keretében végrehajtott NBSZ-szintű szervezeti átszervezést követően 2006-ban a fotó-, videotechnikai szakterület a Szakértői Intézet berkeibe került, és az alábbi feladatok, vizsgálatok elvégzésére volt kirendelhető (és rendelhető ki ma is):

- multimédiás képrögzítők segítségével keletkezett (analóg és digitális) videófolyamatok (nem filmek!), fotók információtartalmának értékelése, feldolgozása;

- tárgy- és személy-összehasonlítás;

- geometriai és képi háttér-információk kinyerése; 
- képjavítás, lényegkiemelés speciális eszközrendszer segítségével: személy, forgalmi rendszám, tárgy (például fegyver) azonosíthatóságának elősegítése; személyek esetében a magasság, gépjármúveknél a típus meghatározásának előkészítése; eseménydetektálás.

A szakértők gyakori feladata volt a 2000-es évek közepén a biztonsági kamerás videófelvételek térbeli és időbeli demultiplexelése (vagyis a biztonságikamera-rendszerekre jellemző „több kamera - hosszú idő alatt rögzített felvétele - gyors lejátszás módban" módszerének felülírása, és a kérdéses kamera felvételének leválogatása normál lejátszási módban), valamint megkísérelték biometriai jellemzők alapján a sorozat-bűncselekmények elkövetése alkalmával készült felvételekről az elkövetők esetleges hasonlóságát, egyezését vizsgálni. 2009-ben szakértői véleménnyel segítettük a nyomozókat a Marian Cozma-gyilkosság ügyben, 2010-ben pedig új feladatként jelent meg a gyanúsítottól lefoglalt ruházat összehasonlítása a bünelkövetést rögzítő biztonsági kamera felvételeivel.

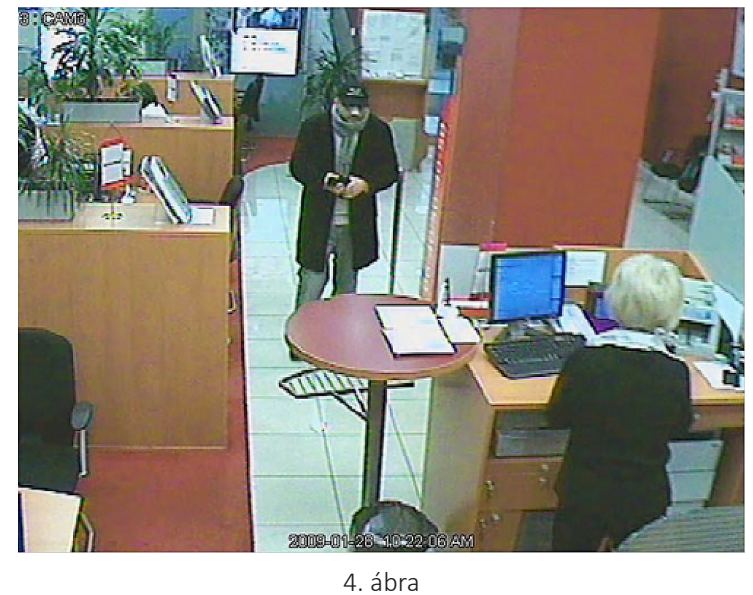

2009. január 28. Duna Pláza, bankrablás az Unicredit bankban

Forrás: https://index.hu/bulvar/bank2252/ (A letöltés dátuma: 2019. 10. 29.)

\section{1-2019: a digitális szakértés megjelenése}

A 2011-es éveket követő korszak meghatározó eseménye az informatikai (számítástechnikai eszközök, úgymint számítógépek és adathordozóik vizsgálata) és mobileszköz-szakértés elindulása (mobil kommunikációs eszközök - mobiltelefonok, navigációs eszközök stb. - adattartalmának vizsgálata). A modern információtechnológiai eszközök elterjedésével mindkét szakértői ágazat rövid időn belül rohamos fejlődésnek 
indult. Az információtechnológiai szakértés a következő feladatok, vizsgálatok elvégzését jelenti:

- Informatikai eszközök (laptopok, merevlemezek, memóriakártyák, optikai lemezek stb.) vizsgálata esetén:

- hiteles adatmentés adathordozókról;

- törölt fájlok helyreállítása;

- adattartalom elemzése;

- kulcsszavas keresés;

- titkosított fájlok dekódolása (jelszótörés).

- Mobiltelefon, GPS-eszköz, SIM-kártya, memóriakártya vizsgálata esetén:

- hiteles adatmentés a mobileszközről;

- törölt fájlok helyreállítása;

- adattartalom elemzése (híváslista, üzenetek, naplóbejegyzések stb.);

- SIM-kártya beazonosítása, hívószámának megállapítása;

- állományok metaadatainak, formátumtól függő egyéb adatainak kiértékelése.

- A malware-szakértés az IT-eszközöket kompromittáló rosszindulatú szoftverek azonosítására, elemzésére és értékelésére terjed ki, amely tevékenységet a szakterületen 2016 óta végezzük.

Az informatikai szakterület létrehozásával kialakult a Szakértői Intézet igazságügyi szakértői tevékenységének mai arculata, és az alábbi módon oszlik meg a megrendelői igény a 2011-2018 közötti kirendelésszámok alapján:

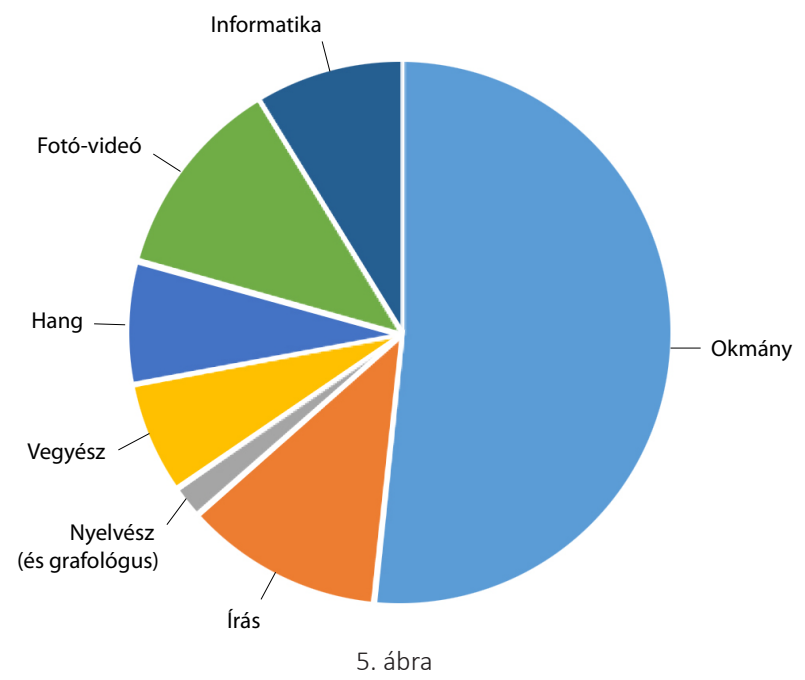

A szakterületi kirendelések aránya 2011-2018 között

Forrás: Nemzetbiztonsági Szakszolgálat Szakértői Intézet (saját szerkesztés) 
Az informatikai szakértői kirendelések összetettségét jelzi, hogy egyetlen év alatt 57,9 TB-nyi adat érkezett a szakterületre. A 2014-es év a nagy mennyiségű adathordozót tartalmazó ügyekről szólt: a Készenléti Rendőrség Nemzeti Nyomozó Irodának (NNI) 164 db HDD-adathordozó, míg a NAV-nak 294 db informatikai és mobilkommunikációs adathordozó vizsgálatát végeztük el. 2018-ban jogosulatlanul vagy a céltól eltérő adatkezeléssel elkövetett személyes adattal való visszaélés vétség gyanúja miatt indított nyomozást az NNI a Nemzeti Adatvédelmi és Információszabadság Hatóság (NAIH) feljelentése alapján a Szcientológiai Egyház ellen. A házkutatás során foganatosított lefoglalás és helyszíni adatmentés megtörtént, közel 40 TB adatot dolgoztak fel. Ugyancsak 2018-ban végeztek a szakértők ATM PC-vizsgálatot a Hajdú-Bihar Megyei Rendőr-főkapitányságnak: az elkövetők az ATM-hez informatikai eszközt csatlakoztattak, és az automatában található 50825000 Ft készpénzt eltulajdonították. A szakértői vélemény alapján a büncselekményt a külső eszközről futtatott malware-törzs felhasználásával hajtották végre.

2016-tól kezdve növekedést mutat a múveleti munkát támogató szakértői kirendelések száma, mintha kezdenénk újra közeledni a kilencvenes évekre jellemző kb. 30\%-os múveleti kirendelési arány felé. Az elkövetőknél még mindig népszerü az Erzsébet-utalványok nyomdai úton, megtévesztésre alkalmas minőségű hamisítványainak előállítása (13 ügyben 2450 db utalványt vizsgáltunk), ezért javaslattal éltünk a gyártó felé az utalványok nyomdatechnikai védelmi rendszerének továbbfejlesztése érdekében. A 2015 és 2017 között a menekültválságra reagálva megnőtt a BÁH-os kirendelések száma mind az okmány-, mind az írásszakértői területeken (az ügyek 80\%-a innen érkezett), 2017-től a migrációs nyomás helyébe a honosítási ügyek miatti vizsgálati igény lépett. 2018-ban egy NNI közokirat-hamisítás bűntettében indított nyomozás során az informatikai szakértői vizsgálatok keretében kinyert (47 adathordozó, 300 GB, kb. 180 ezer fájl leválogatását követően) okmányszakértői szempontból releváns (11 ezer fájlt érintő) információtartalom szakértői vizsgálata történt meg. Ezen lényegi tartalmak alapján arra lehetett következtetni, hogy a gyanúsított több mint 10 éven keresztül végzett hamisítói tevékenységet, aminek keretében nagy számban állította elő személyi igazolványok, vezetői engedélyek, különböző iskolai végzettségeket igazoló bizonyítványok, oklevelek hamis változatait.

2011-ben az Ajkai Rendőrkapitányságnak jelentős értékre üzletszerüen elkövetett sikkasztás bűntette miatt 175 db vételi jegyen lévő kéz- és számírásokat, valamint aláirásokat vizsgáltunk meg és hasonlítottunk össze. Újfent nagy mennyiségú orvosi vény okmány- és írásszakértői szempontú vizsgálatát végeztük el 2015-ben: a vények eredeti formanyomtatványok voltak, legtöbbjük orvosi bélyegzése is eredeti volt, ám a vényeken átvevőként szereplő személyek aláírásainak mindegyike hamisítvány volt. 


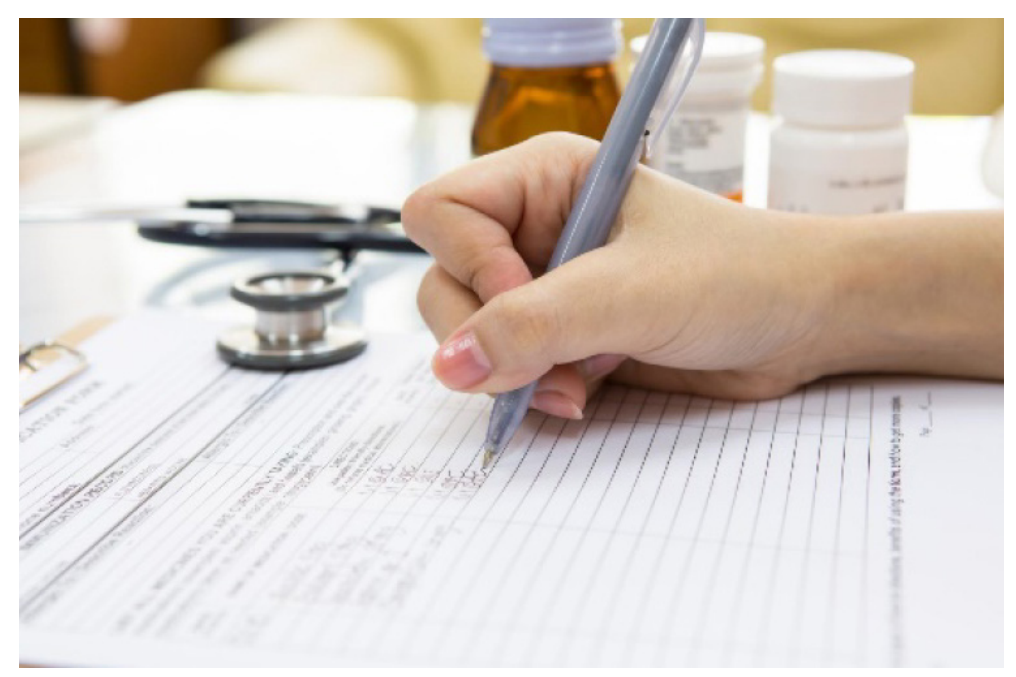

6. ábra

Kéz- és aláírásvizsgálat vényeken

Forrás: www.heol.hu/kek-hirek/helyi-kek-hirek/receptet-hamisitottak-igy-probaltakgyogyszerhez-jutni-1168460/ (A letöltés dátuma: 2019. 10. 29.)

2017-ben a nyelvészek és hangszakértők együttmúködésének eredményeként a Mosonmagyaróvári Rendőrkapitányság sikeresen lezárta a fegyveresen elkövetett rablás bűntettében folytatott nyomozást: telefonlehallgatásból származó hangfelvételek alapján meghatároztuk a beszélői profilt, majd a későbbiekben a beszélőt kategorikusan beazonosítottuk.

Az elmúlt 8 év néhány robbantásos esemény egyike a 2014-es XIII. kerületi CIBbankfiók bejáratának berobbantása volt. Ebben az ügyben a Szakértői Intézet szinte valamennyi szakterülete adott szakvéleményt: a vegyészek a robbanóanyag-maradványokat, a fotó-, videotechnikusok a biztonsági kamerás felvételeket, a nyelvészek névtelen fenyegető levelet vizsgáltak. 2016-ban szintén egy kiemelt jelentőségú robbantásos ügyben kellett a szakértőknek együtt dolgozniuk: a Teréz körúti robbantással összefüggésben a vegyészek a helyszínelés során rögzített mintákat megvizsgálták, a gyanúsítottnál történt házkutatás során vett mintákkal összehasonlították, és azonosították a HMTD-robbanóanyagot. Ugyanezen robbantással összefüggésben a fotó-, videotechnikai szakértők a biztonsági kamerás felvételek vizsgálatát is elvégezték. 


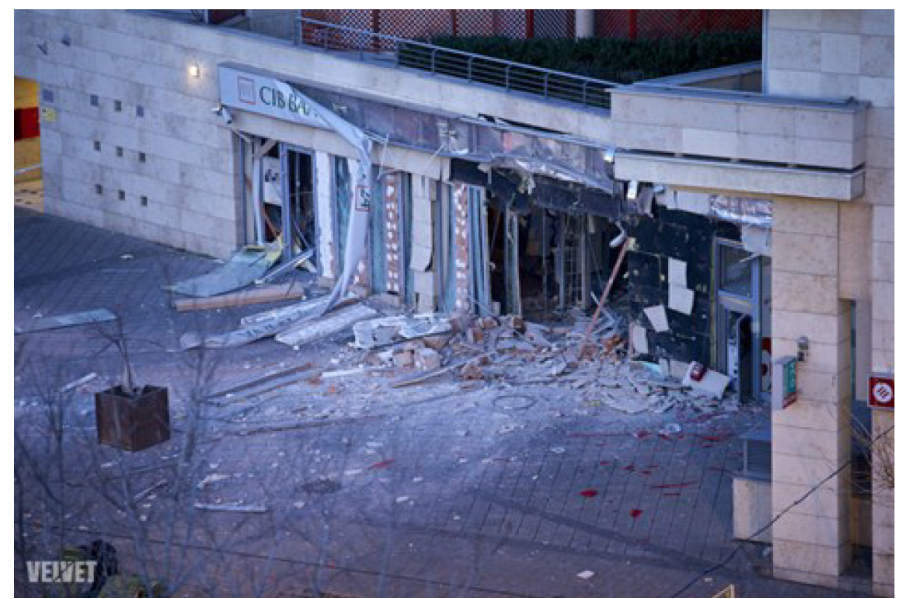

7. ábra

Robbantás a CIB-fióknál

Forrás: www.galeria.index.hu (A letöltés dátuma: 2019. 10. 29.)

Fotó-, videotechnikai szakértőink dolgozták fel többek között a thaiföldi emberrablási ügyben, valamint a gyöngyöspatai eseményekkel kapcsolatban keletkezett képanyagokat. Az időszak egyik kiemelt ügye a különösen nagy értékben (kárérték: 139 millió Ft) elkövetett rablás bűntettében folytatott BRFK-nyomozás, melynek során az elkövetőkről és az általuk használt gépjárműről készült képek javítását végeztük el. 2014-ben a Szegedi Törvényszék hivatalos személy ellen elkövetett emberölés bünügyében keletkezett videófelvételek vizsgálatának elvégezését kérte tőlünk (hummeres gázolás), 2017-ben pedig a bőnyi rendőrgyilkosság ügyében folytatott nyomozást megtámogatandó a fotó-, video- és hangtechnikai területek múködtek együtt.

A hangtechnikai szakterületen OLAF - Európai Csalás Elleni Hivatal - pályázat keretében beszerzésre került egy automata beszélőazonosító rendszer (Batvox), amely a szakértői módszertanba is bekerült, így már hárompilléressé vált a beszélőazonosítás (percepciós vizsgálatok, akusztikai-fonetikai vizsgálatok, valamint az automata rendszer eredményei).

Csaknem kétéves előkészítő munka után, amelyben a szakértői társadalom - így intézetünk is - aktívan részt vett, az Országgyúlés 2016. április 26-án elfogadta az igazságügyi szakértőkről szóló 2016. évi XXIX. törvényt; a korábbi jogalkotói gyakorlattól eltérően a szakértők már kezdettől fogva bekapcsolódhattak az előkészítő tevékenységbe.

2018-ban az Unicredit Bank Hungary Zrt. és a Szakértői Intézet között együttmúködési megállapodás köttetett a digitális aláíró padon készített aláirások szakértése témakörben. A megállapodás célja, hogy a bank által bevezetett, biometrikus aláírásokon alapuló szerződéskötési módszer keretében tett biometrikus aláírás vizsgálatához olyan zárt, biztonságos rendszert alakíthasson ki, amely alkalmas a biometrikus aláírás - esetenként 20 évvel - későbbi írásszakértői vizsgálatára. 
2019-ben került átadásra az OLAF-pályázat keretében megvalósult a Chip-off labor, amely az informatikai szakterült adatmentési képességének továbbfejlesztésében jelent áttörést; tudniillik a sérült, használhatatlanná vált, megrongált mobileszközökön tárolt adatok kinyerésére a laborban az adathordozó chip kiemelhető, vagy az adattároló chiphez közvetlenül lehet csatlakozni, onnan adatot letölteni a müködőképesség megőrzésével: JTAG-technológia, In-System-Programing (ISP) eljárás.

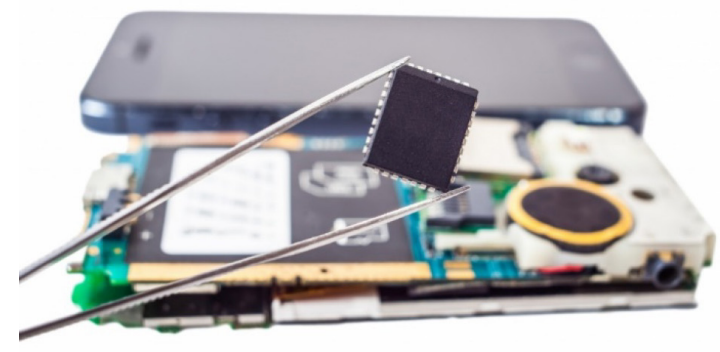

8. ábra

Chip kiszerelésén alapuló adatkinyerés

Forrás: https://blog.salvationdata.com/2018/04/04/case-study-chip-off-forensics-how-to-extract-data-fromdamaged-mobile-devices/ (A letöltés dátuma: 2019. 10. 29.)

\section{Kitekintés}

Az akkreditálás igénye már a 2000-es évek környékén felmerült, először a vegyész szakterületen, ám nem valósulhatott volna meg az NBSZ vezetésének támogatása nélkül; vezetőink meglátták a lehetőséget a minőségirányított rendszer biztosította garantált minőségben. A belső igények mellé hamarosan külső, nemzetközi elvárások is társultak. Az akkreditáció sarkalatos pontja a vizsgálólaboratóriumok jártasságának kérdése: az intézetben múködő legtöbb szakterület évente részt vesz az Európai lgazságügyi Szakértői Intézetek Hálózatának (ENFSI) adott munkacsoportja által készített, valamint az igazságügyi szakértői intézetek számára kidolgozott tesztprogramokban (Collaborative Testing Services Inc. - CTS), amelyek igazolják az egyes vizsgálólaboratóriumok vizsgálati módszereinek érvényességét.

2003-ban a Robbanóanyag Laboratórium (RAL) volt az első vizsgálólaboratórium, amely elnyerte intézetünkben a Nemzeti Akkreditáló Hatóság (NAH, korábban Nemzeti Akkreditáló Testület - NAT) által az akkreditált státuszt, amelyet mára valamennyi szakterület követett. 2008-ban vált akkreditálttá az Okmányszakértői Laboratórium (OSZL), 2013-ban az Írásszakértői Laboratórium (ÍSZL), 2017-ben pedig a Hangtechnikai Szakértői Laboratórium (HSZL), a Nyelvész Szakértői Laboratórium (NYSZL), valamint a Fotó-videotechnikai Szakértői Laboratórium (FVSZL). 2019-ben már az informatikai szakértői terület is minőségirányított rendszerben müködik. A Szakértői Intézet a Nemzeti Akkreditáló Hatóság által NAH-1-1206/2019 nyilvántartási számon akkreditált szervezet, amelynek részei a vizsgálólaboratóriumok; ennek keretében valamennyi, 
a megrendelő (kirendelő) szerv által átadott irat, dokumentum stb. vizsgálatára pontosan körülírt és ellenőrzötten végrehajtott vizsgálati módszereket alkalmazunk. A vizsgálatok során készült, dokumentált feljegyzések, valamint képi illusztrációk felhasználásával történik a szakértői vélemények összeállítása. Az ügyben szakvélemény adására kijelölt szakértő tevékenységét konzultáló/ellenőrző szakértő kontrollálja, ezáltal igyekszünk biztosítani a szakvélemények szakmailag korrekt, tévedésektől, illetve hibáktól mentes kialakítását.

A minőségirányított rendszer múködtetése mellett cél a nemzetközi igazságügyi szervezetekhez való tartozás. Az ENFSI kapcsolatok minden szakterületen a szakmai fejlődés zálogai, lévén európai (és nemzetközi) szinten elérhető tudást, valamint szakmai fejlődési lehetőséget is biztosít. 2005-ben váltunk társult taggá a robbanóanyagvizsgálati (FINEX), 2006-ban az okmányszakértői (EDEWG), 2007-ben az írásszakértői (ENFHEX), 2008-ban a digitális képfeldolgozó (DIWG), 2012-ben a kábítószer-vizsgálati (DWG), 2013-ban pedig a bünügyi információtechnológiai (FITWG) és a hangtechnikai (FSAAWG) munkacsoportokban.

\section{Összegzés}

Az intézet szakterületei között szoros az együttmúködés, amely egyrészt megteremti a lehetőségét annak, hogy komplex vizsgálatok végrehajtására kerüljön sor több szakterület részvételével, másrészt esélyt ad arra, hogy az egyes szakterületek szakértői a tudásukat megosszák. A Szakértői Intézet feladatait illetően sok a szakmai átfedés, határterület, így valósul meg a szakmai együttmúködés.

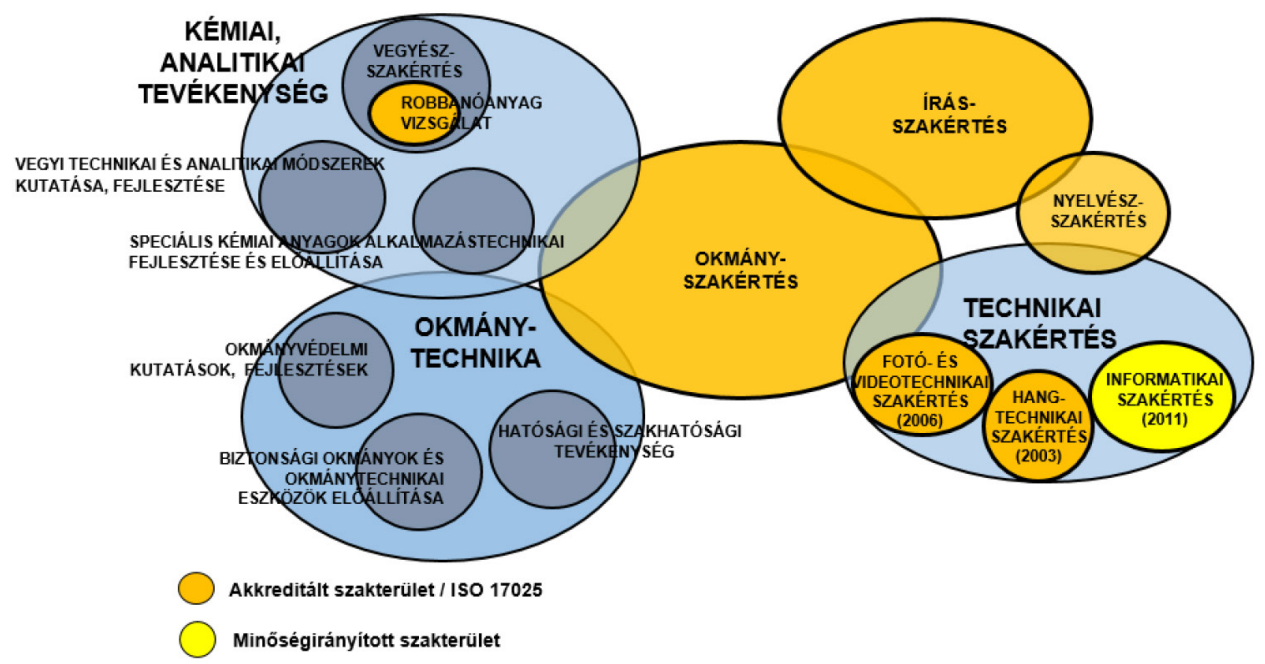

9. ábra

A Szakértői Intézet szakértői tevékenysége napjainkban

Forrás: Nemzetbiztonsági Szakszolgálat Szakértői Intézet (saját szerkesztés) 
A Szakértői Intézet hazai és nemzetközi viszonylatban sem számít nagy forenzikus intézménynek, közel 80 szakértő tevékenykedik napi szinten támogatva a nemzetbiztonsági szolgálatok, a nyomozó hatóságok és az igazságszolgáltatás munkáját. A humán erőforrás mérete alapján kár lenne megítélni az intézetben folyó munka fontosságát: a Szakértői Intézet szakértői tevékenységének kulcsa egyfelől a kreativitás, amely a múveleti munkavégzésből táplálkozik, másfelől a szakszerűség, amelynek alapja a minőségirányítási szemlélet. Müveleti szakban az adott vizsgálati anyaggal kapcsolatban gyorsan kell nyilatkozni, nem ritkán több szakterülettel együttesen, így a véleményalkotás, az együtt gondolkodás kreatív feladatmegoldásokat eredményezett az idők folyamán, amely módszereket a nyílt szakos vizsgálatok során is kamatoztatni tudunk. És hogy mennyire sikeresen, azt a megrendelőink tudják igazán megítélni.

\section{Felhasznált irodalom}

HAZAI Lászlóné (2014): Az NBSZ szakértői tevékenysége, szakértői képzés. Nemzetbiztonsági Szemle, 2. évf. Különszám. 30-39.

TATÁR Zoltán - OSzTERTÁG János - MORBER Szilárd Krisztián (2019): Technikai szakértői szakterület fejlődése a feladatok tükrében. Belügyi Szemle, 67. évf. 1. sz. 108-117.

\section{Internetes források}

https://origo.hu/gazdasag/20040218megszuntetnek.html (A letöltés dátuma: 2019. 10. 17.)

www.heol.hu/kek-hirek/helyi-kek-hirek/receptet-hamisitottak-igy-probaltak-gyogyszerhez-jutni-1168460/ (A letöltés dátuma: 2019. 10. 17.)

https://blog.salvationdata.com/2018/04/04/case-study-chip-off-forensics-how-toextract-data-from-damaged-mobile-devices/ (A letöltés dátuma: 2019. 10. 17.) https://index.hu/bulvar/bank2252/ (A letöltés dátuma: 2019. 10. 17.)

www.mare.info.hu (A letöltés dátuma: 2019. 10. 17.)

www.galeria.index.hu (A letöltés dátuma: 2019. 10. 17.)

\section{Jogforrások}

1990. évi X. törvény a különleges titkosszolgálati eszközök és módszerek engedélyezésének átmeneti szabályozásáról

1995. évi CXIV. törvény az igazságügyi szakértői kamaráról

1995. évi CXXV. törvény a nemzetbiztonsági szolgálatokról

2016. évi CL. törvény az általános közigazgatási rendtartásról

2016. évi XXIX. törvény az igazságügyi szakértőkről

282/2007. (X. 26.) Korm. rendelet a szakterületek ágazati követelményeiért felelős szervek kijelöléséről, valamint a meghatározott szakkérdésekben kizárólagosan eljáró és egyes szakterületeken szakvéleményt adó szervekről

86/1996. (VI. 14.) Korm. rendelet a biztonsági okmányok védelmének rendjéről 